\title{
Regimes, Social Risks and the Welfare Mix: Unpacking Attitudes to Pensions and Childcare in Germany and the UK Through Deliberative Forums
}

\author{
PETER TAYLOR-GOOBY* (D), JAN-OCKO HEUER ${ }^{* *}$, HEEJUNG CHUNG***, \\ BENJAMIN LERUTH****, STEFFEN MAU***** AND \\ KATHARINA ZIMMERMANN*****
}

* School of Social Policy, Sociology and Social Research, University of Kent, UK email: P.F.Taylor-Gooby@kent.ac.uk

**Department of Social Sciences, Humboldt-Universität zu Berlin, Germany email: jan-ocko.heuer@hu-berlin.de

*** School of Social Policy, Sociology and Social Research, University of Kent, UK email: H.Chung@kent.ac.uk

**** Institute for Governance \& Policy Analysis, University of Canberra, Canberra, Australia email: Benjamin.Leruth@canberra.edu.au

****** Department of Social Sciences, Humboldt-Universität zu Berlin, Germany email: steffen.mau@hu-berlin.de

******* Department of Social Sciences, Humboldt-Universität zu Berlin, Germany email: katharina.zimmermann@hu-berlin.de

\begin{abstract}
Modern welfare regimes rest on a range of actors - state, market, family/households, employers and charities - but austerity programmes diminish the contribution of the state. While changes in this 'welfare mix' require support from the population, attitude studies have focused mainly on people's views on state responsibilities, using welfare regime theory to explain differences. This paper contributes to our understanding of the welfare mix by including other providers such as the market, the family or employers, and also introduces social risk theories, contrasting new and old risks. Regime theory implies differences will persist over time, but risk theory suggests that growing similarities in certain risks may tend to promote international convergence. This article examines attitudes to the roles of state, market, family, charity/community and employer for pension and childcare in Germany and the UK. We collected data using deliberative forums, a new method in social policy research that allows citizens space to pursue extended lightly moderated discussion and permits researchers to analyse people's justifications for their attitudes. Our research indicated patterns of convergence especially in preferences for childcare, but that regime predominates in people's justifications for their attitudes: regime differences in attitudes are resilient.
\end{abstract}




\section{Introduction}

Modern welfare rests on provision by three agencies: state, market and family, with additional support from the community and charities, employers and others. The role of government in this welfare mix is generally shrinking, under pressure from austerity programmes and as ageing populations demand extra support which the state finds hard to provide (Taylor-Gooby, 2017). Popular ideas about the responsibilities of the various actors in the welfare mix matter because a shift towards greater private or family contribution requires the active engagement of the population and because changes in the mix will only succeed in the long term if people accept them.

Much discussion of attitudes to the role of the state in the welfare mix has been shaped by regime typologies (Svallfors, 1997; Arts and Gelissen, 2001; Jæger, 2006), focused on state provision and on state and market interactions. Risk approaches, which distinguish between the 'old' risks of industrial society and the 'new' risks of post-industrialism and emphasize the additional roles of family, employers and other actors in provision, have received less attention. In this paper, we combine the two perspectives by exploring citizens' attitudes towards the welfare mix: more specifically, how they are shaped by regime legacies and existing patterns of provision on the one hand; and judgments on specific social risks and needs and the circumstances surrounding a particular service on the other. We study preferred responsibilities for welfare provision in two contrasting services, pensions and childcare, typifying old and new social risks at different life-course stages, in two contrasting countries, Germany and the United Kingdom (UK), exemplifying more corporatist and more liberal regime-types (Esping-Andersen, 1990). These issues of responsibility in different regimes and for different risks form the basis of our research questions:

1) Do attitudes to responsibility for pensions and childcare differ substantially between Germany and the UK, reflecting regime membership?

2) Do attitudes to responsibility for pension and childcare differ substantially between the two service-areas in these countries, reflecting a distinction between social risks and responsibility for them?

We use an innovative qualitative method: democratic forums or 'mini-publics' (for more details, see Taylor-Gooby and Leruth, 2018), reflecting the demographic make-up of the population and meeting for extended discussions with opportunities to call on experts for information and advice.

The paper makes three contributions to comparative social policy: it moves beyond the common focus of attitude research on state responsibility for social welfare; it shows how both regime and social risks shape people's preferences about responsibilities and the role of different actors in the welfare mix; and, most importantly, it demonstrates the usefulness of democratic forums as an 
innovative method for studying welfare attitudes that provides new information on the clusters of ideas that underlie the attitudes reported in structured surveys.

Section 2 discusses relevant theory and literature. Section 3 presents the cases, data and methods. Section 4 analyses responsibility attributions in the two policy areas in both countries and the underlying perceptions of actors. Section 5 discusses the findings and concludes.

\section{Background literature}

'Welfare mix' denotes the varying configurations of actors in the production of welfare. The concept originated in the 1980s and was used to challenge the common dichotomy in social policy research between state and market (e.g. Esping-Andersen, 1990), as it highlights the importance of the family and the internal division of work within the household (Lewis, 1992; Sainsbury, 1994) and of actors such as the community, non-profit organisations or employers (Evers, 2011; Jenson, 2015). As the welfare mix 'constitutes the centre of gravity of welfare regimes' (Powell and Barrientos, 2004: 86), the differing actor configurations have been used to classify such regimes (for example, EspingAndersen, 1999) and to explore changes over time. Diagnoses such as 'marketisation', 're-familialisation', or 'responsibilisation' point to an overall trend towards the partial retreat of the state from welfare production and a corresponding greater role for markets, families and other actors (e.g. Ascoli and Ranci, 2002; Daly, 2011; Natali et al., 2018). These developments are driven by different competing forces in different social contexts and can move in different directions (Lodigiani and Pesenti, 2014). Discussion of the complexity of different configurations of non-state provision (for example, the distinction between financing, administering, regulating and providing a service) are not fully developed here since such factors are not usually included in lay attitudes.

Although these changing configurations of welfare require democratic legitimation and, typically, greater citizen involvement, the main focus of attitude research has been on the responsibility of the state for welfare production. For example, successive rounds of the International Social Survey Programme (ISSP, 2018) and the European Social Survey (ESS, 2018) include a series of questions on state responsibility without equivalent questions on the responsibilities of other actors. Although studies based on these datasets find strong support for government responsibility (Svallfors, 2012; Chung and Meuleman, 2017), the lack of material on alternatives to state-provided welfare might influence responses.

Few cross-national studies go beyond studying responsibility attributions towards the state (for a review, see Chung et al., 2018a). Svallfors (2007) examines attitudes towards market-induced inequalities in four countries and finds that Britons are most accepting of opportunities to buy better healthcare and education services through the market, whereas Germans and Swedes are most 
sceptical. Lindh (2015) includes 17 countries and finds generally little support for market distribution of social services, but higher support in countries where private spending on services is already higher, leading to the conclusion that 'popular beliefs about the role of the market are shaped by the actual role that markets play' (Lindh, 2015: 904).

Although these studies move away from the traditional focus on state-provided welfare, they focus exclusively on market-provided welfare and fail to take other welfare providers into account. Moreover, by equating market provision with inequality, they do not explore other perceptions of actors and the attitudes and reasoning that lead citizens to favour specific actor constellations. Finally, qualitative research indicates that welfare attitudes can be uncertain, inconsistent and ambivalent or non-existent (Goerres and Prinzen, 2012). Research designs that capture the complexity and potential ambivalence of attitudes are necessary to study actor configurations in the welfare mix (Burkhardt et al., 2011; Mau and Sachweh, 2014).

In this paper, we study attitudes to the welfare mix from two directions: the extent to which attitudes vary between different welfare regimes, and between different benefits and services. We follow Svallfors (1997), Arts and Gelissen (2001) and Jæger (2006) in using regime approaches to identify contrasts between state and market providers across countries, distinguishing here between corporatist-conservative regimes such as Germany, with its strong emphasis on status maintenance, foregrounding the state and the family, and liberal regimes such as the UK, where market and individual responsibility plays a more important role.

We also use new risk approaches (Taylor-Gooby, 2004; Bonoli, 2005) to analyse differences in attitudes to benefits and services. The new risk literature distinguishes the long-run benefits and services of the welfare state designed to deal with the common risks of industrial society (via old-age pensions, healthcare and transitional unemployment benefits) from those that address the risks of postindustrial society (to do with reconciling work and family life and maintaining skills for a changing labour market; $c$. Fossati, 2018). The new risk approach also takes into account a more multifaceted combination of actors, such as employers, families, and communities/charities, allowing us to better understand people's diverse and nuanced preferences. For the purpose of this paper, we will focus on pensions and childcare services as examples of old versus new risks.

Both regime and risk theory contribute to our analysis. We expect that the different traditions, institutions and ideologies of different regimes will produce distinctive attitudinal patterns. More specifically, we expect preferences among German participants to favour state provision that reinforces the status-divisions of the world of work as well as family provision, in line with the 'male breadwinner' model of conservative welfare states. People in the UK will tend to support a stronger role for the market and family rather than the state. 
We also anticipate a distinction between new and old risks in the degree to which regime differences can be found. Country (regime) distinctions will be much more evident in pension policies for three reasons: firstly, pensions developed in predominantly industrial societies where regime differences were more marked; secondly, pensions relate more obviously to income replacement, redistribution and ideas about deservingness which differ between regimes (Blekesaune, 2013); and thirdly, current debates around welfare state sustainability direct attention to pension finance which differs between countries (Taylor-Gooby et al., 2017). In contrast, provision in the new risk area of childcare developed only recently in both countries (Ferragina and Seeleib-Kaiser, 2015; Chung and Meuleman, 2017). Childcare has been widely promoted as social investment despite austerity (Deeming and Smyth, 2015; Chung et al., 2018 b). It increases the size of the labour force because it helps parents, especially women, to take paid jobs (Vandenbroucke et al., 2011; Ronchi, 2018; Morel et al., 2012; Lister, 2004). In sum, we expect regime differences to be more marked for pensions than for childcare.

\section{Cases, data and methods}

\subsection{Countries and policy areas}

The countries and policy areas are chosen to provide substantial contrasts between regime types and risk-areas and services. Pensions are a well-established, high-spending area where there have been many reforms to contain spending in both countries. By contrast, childcare has emerged relatively recently as a state service, involves lower expenditure, and is still expanding. Comparison of the two areas juxtaposes old and new social risks, contrasts interests between women and men and older and younger life stages, and involves an allocative as opposed to a social investment approach. These factors lead to a contrasting politics of welfare. While pensions are understood mainly in terms of their contribution to the living standards of older people, childcare can be approached in two ways, for its economic contribution in enabling parents (in practice, mainly mothers) to work, and for its social contribution in facilitating child development and supporting family life. Although many commentators distinguish between childcare needs for babies, toddlers and older pre-school children, with the EU distinguishing between under $3 \mathrm{~s}$ and 3 to school age in its analysis (Eurostat, 2018), we are unable to make such distinctions since the participants in our forum did not pursue them. Germany, particularly the former West Germany, is the paradigmatic conservative welfare regime with relatively low support for market provision and low acceptance of market-induced inequalities. By contrast, the UK is the most clearly liberal regime in Europe with the highest level of support for market services among the 17 countries studied by Lindh (2015) and high acceptance of market inequalities (Svallfors, 2007). 
The institutional framework for provision in the two areas reflects regime differences but has been subject to further development. The old-age pension system of former West Germany was traditionally a prime example of a Bismarckian pension system, with 'pay-as-you-go' public retirement insurance linking benefits to earnings-related contributions and offering high replacement rates, ensuring status maintenance in old age. Since the 200os, reforms aiming at cost containment have included a considerable decrease in public pension levels, a gradual rise in the retirement age, and a move towards a multi-pillar system including a voluntary but state-subsidized private pension ('Riester-Rente'). The assets of funded pension schemes increased from 4.2 per cent to 6.8 per cent of GDP between 2006 and 2016 (OECD, 2018). A needs-based basic pension at social assistance level was also introduced to counter growing old-age poverty. The current situation is characterized by growing state subsidies to curb contributions to the public retirement scheme, expected further falls in public pension levels, low take-up of private pensions, and a growing number of people in need of a basic pension.

The UK pensions system of the early 2000 s was complex, consisting of defined-benefit national insurance pensions financed by contributions from employers, workers and government and dependent on work record; top-up occupational pensions mainly for middle class and state sector workers and state-subsidised by tax exemptions; a small private pension sector used by the top five per cent; and a tax-financed means-tested pension. The new emerging system consists of flat-rate defined-benefit national insurance pensions with a basic work-record condition met by almost all workers, and a quasimandatory top-up pension for most workers financed by employers and workers and with a relatively low replacement rate. Employees can opt out of the top-up and lose the employer contribution. Funded pensions are significant and grew from 76.8 to 95.3 per cent of GDP between 2006 and 2016 (OECD, 2018).

German childcare policies have changed considerably in normative, institutional and organisational respects (Ostner, 2010). Until the 1990s, West Germany was a typical example of a 'male breadwinner' model that fostered male standard employment and female housekeeping and childrearing. Although kindergarten (childcare between age three and school age) has been widely provided and utilised since the 1980s, there was almost no provision for children up to the age of three. On the other hand, in the former German Democratic Republic, the socialist regime made public childcare widely available, so that the majority of children, even those aged between o and 3 , had access to formal childcare. This tradition remains even now and despite the faster rate of expansion of childcare in West Germany in the past decade, the proportion of children between 0 and 3 in formal childcare was 22.3 per cent and 49.0 per cent in West and East Germany respectively in 2012 (Oliver and Mätzke, 2014). There are indications of attitudinal shifts: recent 
quantitative studies show that normative beliefs in Germany are moving away from the traditional argument that mothers' employment hinders their children's wellbeing (Blome, 2016). Policies to promote women's employment and improve reconciliation of work and family life include the introduction of a legal right for children aged 1 and above to childcare, and a generous paid parental leave scheme which includes an earmarked leave for fathers. Childcare facilities are run mainly by public and private non-profit providers, such as welfare associations or parents' initiatives, with structures, costs and availability differing considerably between federal states and even more among municipalities. However, the majority of the fiscal responsibility remains with the state (Oliver and Mätzke, 2014).

Childcare provision in the UK was relatively underdeveloped with work/ family reconciliation considered a family responsibility until the late 1990 (Lewis et al., 2008). Despite recent developments (longer maternity leave, shared parental leave and further rights to request flexible working), public childcare provision remains weak. A right to part-time childcare for three-year-olds was introduced in 2008 and extended in 2017 from 15 to 30 hours, conditional on the wages and working hours of parents and covering two-year-olds for families in need. The UK government also contributed to childcare fees for the very poorest parents through Tax Credit. However, the UK has one of the most expensive childcare systems in the OECD (OECD, 2016), averaging $\mathfrak{E} 230^{2}$ a week in 2016 for a full-time place. In 2015, the UK did not meet the EU target of 33 per cent of children aged o to 2 in formal childcare, reaching only 30 per cent overall, with only 4.3 per cent of those between $\mathrm{o}$ and 2 in full-time childcare. Moreover, formal childcare coverage has not improved since 2005; in fact, it fell between 2008 and 2016 (Eurostat, 2018). The government has also curtailed many programmes for low-income families, including the Sure Start programme of integrated children's day nurseries, and cut Tax Credit, which included a family component.

In sum, regime differences in pensions remain marked, but additional private pensions have been introduced, quasi-mandatory in the UK but voluntary in Germany, and these have expanded. Childcare has developed rapidly in both countries and extended downwards to children below three years old, cross-cutting traditional national assumptions about family and state/market responsibilities.

\subsection{Data and methods}

This is an exploratory study of a complex area that has so far received little attention from attitude researchers. We use a qualitative approach to explore the structure of people's ideas. The method, democratic forums, promises to provide rich and detailed material on people's priorities and how they understand them (Taylor-Gooby et al., 2018: ch1). Such forums have been used most frequently in previous work to generate public agreement on contested policy issues 
(e.g. Fishkin and Luskin, 2005) and in more theory-driven approaches to democratic institution-building (e.g. Wakeford and Singh, 2008; Grönlund et al., 2014) but not in relation to social policy. Our forums were extended discussions taking place with an identical design in both countries in autumn 2015 over two days among citizens chosen by gender, age, educational qualification, employment status, household income, family status and children in the household, migration background and minority status, and political preferences to reflect broadly national demographic characteristics (34 participants in each country). At the time public debates were dominated by other issues - the refugee crisis in Germany (Forschungsgruppe Wahlen, 2015) and crime, defence and Brexit in the UK (IPSOS-Mori, 2015). The method emphasises the degree of participants' control over the discussion, with very limited intervention from the research team. Participants were free to develop and discuss the initial question ('What should the priorities of the [German/British] government be for benefits and services in 25 years' time?'), with only light moderation and with opportunities to call on experts for information and advice. The groups were asked in the final session to come up with bullet points for a report on policy priorities to be pursued during the next 25 years, to give focus to the discussion.

On the first day, the forums met in a plenary session for the initial question to be introduced and discussed and any requests for information to be made. They then formed smaller groups (10-12 members) to discuss the various areas they identified as important. They met again in a plenary at the end of the day to present a summary of the discussion and to request further information. Both groups requested further information on the current and likely future numbers of recipients and costs to the individual and the government for pensions and childcare provision. The information was derived from official reports and provided by email before the second meeting and again at the beginning of the second day of meetings, where there was an opportunity to discuss it in more detail. Participants once again formed smaller discussion groups and met again in a final plenary to vote on policy priorities for the report. All discussions were audio- and video-recorded. The research generated a large volume of material with more than 36 hours of discussion in each country. Moderators made sure that no one individual dominated discussion and that there were good opportunities for all viewpoints to be included, as the range of participants' views quoted below indicates.

Written transcripts from the deliberative forums were analysed using framework analysis (Ritchie et al., 2003). This is an iterative process of identifying the main attitudinal themes in relation to each topic and then examining their relationship in the discussion. Six nodes were used in NVivo coding to identify statements relating to responsibilities: government/public sector; market/private sector; individual; family; employer; and community/charities, reflecting the categories used by the participants. Contrasting statements on 
the welfare mix were identified and the discussion around these statements analysed iteratively to trace the development of ideas and the arguments used to justify particular priorities and choices for the assignment of responsibilities. Further details of the democratic forum method and its relevance to attitude research are available in further project publications (Taylor-Gooby and Leruth, 2018).

\section{Results: responsibility attributions for social welfare in Germany and the UK}

\subsection{Old-age pensions}

In the German democratic forum, old-age pensions were a highly salient topic with little disagreement regarding both the assessment of the current situation and preferences for the future. The pressures on public pensions were reflected in the discussions, with a high degree of consensus that the current pension system is unsustainable because of the ageing German population and the growth of income inequalities. Three problems were identified, the most pressing being the fall in replacement rates and resultant increase in old-age poverty. The second was intergenerational injustice, as participants argued that the current working generation has to pay twice: for the pensions of current retirees via the public pension scheme, and for their own pensions via private schemes (" . . f fairness refers to the younger people too . . they will pay more and more pension fees that they will likely not get back later'; DE-21). A third and more controversial issue was the existence of separate pension schemes for civil servants and self-employed persons, which many participants saw as a hindrance to a fair and sustainable pension system, while some members of these separate schemes defended their status.

Regarding preferred responsibilities, there was a broad consensus that the state/government should be responsible for a needs-based basic pension to prevent old-age poverty: 'The basic social security income has to be set up in such a way that problems of elder-poverty don't arise' (DE-32). Participants set the level of this basic pension at or above the social assistance level, and they agreed that it should be financed via taxes to avoid further strain on the public pension insurance scheme. This pension should be universally available, with the only condition being 'need'. This was described, in the final plenary, as follows: 'solidarity pension or social pension or something like that. It's just that everyone should get something so that they can get by' (DE-23).

A broad majority of participants saw the state as also responsible for old-age pensions beyond subsistence level. Most suggestions roughly reflected the existing public pension insurance scheme, but with two noteworthy differences. First, the participants seemed to have largely accepted that the public pension system cannot ensure individual status maintenance; thus, they primarily argued 
for the continuation of status distinctions based on the reasoning that if all retirees have to get by with less, at least status differences should be upheld. Second, these status differences should be determined mainly by the number of years worked. This approach contrasts with the current public pension scheme which links payment to the previous income level: 'You have to have a pension that is related to the pay-in period, a subsidiary pension ... a bonus for every year to reflect the pay-in period' (DE-09).

A contested issue here was the treatment of unpaid work, such as care and childrearing. While most participants supported a recognition of childrearing periods for pension entitlements, many also seemed to value paid work higher and thus preferred a graduated approach. Some even explicitly argued against 'abuse' by non-working mothers, partly with undertones against lower-class people or immigrants: 'I think this is a big problem. There are many women who never work and probably never will, but they stay at home and have ten children. Or let's say five. And they get a lot of pension points, although they've actually not done anything' (DE-14). Yet, despite these controversies, there was agreement about state responsibility for a graduated pension scheme that reflects the duration of working life or other activities deemed as a contribution to society.

Finally, most participants - while they acknowledged that under current conditions private provision is necessary - favoured private provision only to top up state pensions. The few participants who generally favoured a larger role for private provision pointed to a sense of independence and self-determination: 'It is better if I get more money now and invest for myself, because in 45 years, I don't even know if Germany will still exist, let alone whether or not I'm guaranteed a pension payment. So I'd rather save for myself (DE-14).

In sum, participants argued for a three-level pension system, with a needsbased state pension to ensure basic security and prevent old-age poverty at the first level; an additional state pension reflecting years of paid - and, possibly, unpaid - work at the second level; and a voluntary private pension option via the market at the third level. In this view, the state represents needs-based basic security and preservation of work-based status distinctions, while the market is associated with voluntary choice and the possibility of individual status maintenance.

In the UK, unlike Germany, there was no consensus over the state's responsibility for a minimum state pension to prevent old-age poverty. In contrast, the majority of participants agreed that the current system is unsustainable and puts much strain on the welfare state. This emerged especially after participants were made aware of the likely 25 per cent rise in pension costs by 2044-2045 (OBR, 2015) in the information on demographic pressures provided in response to participants' request. Some participants believed that the state pension will eventually disappear due to lack of funding: 'I think anybody now that's of working age, 40 or 50 or $30 \ldots$ doesn't really believe there'll be any money left in the pension pot for 
us' (UK-84). This reflects the German participants' concern with intergenerational injustice. There was a broad consensus that contributing to private occupational pension schemes should be made compulsory 'to take the pressure off the government, so more businesses have to provide private pensions' (UK-67).

Participants also criticised a lack of transparency when it comes to pensions and the financing of the welfare state: 'I don't know where the money goes that you pay to a pension.... So perhaps the government ought to explain things a little bit more in detail to us . . . because we don't know. I mean, does anybody know where the money goes when you pay into your pension?' (UK-41)

Participants were divided over whether the current state pension policy would or should continue in 25 years' time. On the one hand, some believed in the full privatisation of pensions, emphasising individual responsibility and greater transparency: 'It's giving more ownership because those companies will send you a breakdown of what they're doing with your money as opposed to it going in this big pot that's paying for all kinds of stuff that we don't even realise, and then there's going to be nothing left in that pot. It's a personal thing and you can see what your money's doing, what it's made that company and how much you're going to get back' (UK-86). The ageing population is also seen as challenging sustainability: 'in 25 years' time... because of increases in the NHS and people living longer, and more people at retirement age, it's just going to be impossible to do the maths. And that's why we came to that conclusion that it's going to be a totally different system in 25 years' time than it is today, because you're going to have... 20-25 million [people over 65]' (UK-86). On the other hand, others thought state pensions should be supported, as they 'maintain a good quality of life for those who have paid in' (UK-44) and help retired people 'not to be a burden' (UK-45).

In the final plenary there was a broad consensus over where responsibility for old-age pensions in the UK should lie. Responsibility should gradually shift from the state to the individual, and all workers should be required to contribute to additional private pensions. However, participants could not agree over the role and sustainability of the state pension in 25 years' time (see also Schøyen and Hvinden, 2018), with some arguing that it should be scrapped, others believing that it will be too expensive, and other groups thinking that the state should retain a role in preventing old-age poverty. This contrasts with the German group where almost everyone saw pensions, especially those protecting basic levels of income, largely as a state responsibility. The difference reflects regime with UK participants supporting a shift towards the marketization of risks and those in Germany being more concerned with state involvement and status differences.

\subsection{Childcare}

Childcare policies in Germany attracted greater controversy in discussion than pension policies, but most participants supported the shift towards an 
increased role for welfare providers other than the family. Many of them also pointed to the failure of the new policies to provide enough day-care places to meet their targets - 'the politicians promise these kinds of things, but the reality is different' (DE-06) - and the complex application procedures: 'We really had to apply, like for a job. [...] And with an application interview and steps taken as soon as you know you're pregnant' (DE-30). Four requirements were demanded for childcare facilities: better availability of places; better quality and payment of personnel; longer opening hours; and more flexible opening hours. Most participants did not distinguish childcare issues by age-group and were not concerned whether a facility was run by a public or a private (non-profit) provider. Some suggested: 'if it's the basic responsibility of the state to run day-cares - they could create a framework where building sites are made available, but groups like AWO [welfare association] or whatever they're called could find private initiatives and then start day-care facilities themselves' (DE-29).

Most participants saw childcare in terms of its socio-economic contribution and stated that they preferred professional childcare: 'Personally - well, either you create more day-care spots and offer this service and support, or else you give the parents money so that they can stay at home. I see the focus being more with the day-care option' (DE-27). On the other hand, participants accepted that parents should be able to choose home childcare and argued for the recognition of childrearing periods for pension entitlements: 'But primarily we want to make sure that women who stay at home to take care of the children are not disadvantaged by doing that, but it shouldn't be the model of the future' (DE-11).

In the few cases where a preference for home childcare was expressed, participants justified this with the personal commitment and emotional involvement of parents: 'I find the parents' initiative much, much more important, because the parents have different values and interests in raising the children than those people who are getting paid to take care of them .... I was at home for my children, and I would do it again. That was extremely important for my children' (DE-15). Overall, more involvement of fathers in childrearing was demanded, which should be encouraged by the state: 'That you put forward a concept with men as positive examples of this and not as negative, saying they're a sissy for staying home and cooking and cleaning or what have you' (DE-24).

Finally, participants mentioned employers as a key actor besides state and family. Participants came up with several suggestions for more family-friendly work arrangements, such as working from home, sabbaticals, flexible working hours, or a short-term family leave scheme modelled on the paid parental leave scheme. Many thought employers should be responsible for offering day-care: '... like Frau Merkel has it, where they can bring their children to work and have their own day-care facility there at the office, and ... spend time with their children during breaks and so forth. They could do this at every workplace' (DE-26). While employers were expected to staff their day-care facilities, 
participants believed that there was a role for governments to play - such as offering subsidies. The pooling of childcare facilities was also mentioned as a way to cut costs for companies.

The main expectation towards the state was that it creates a framework and offers financial compensation for parental leave, day-care, and flexible work arrangements, but otherwise refrains from intervention. One participant summed up the discussion: 'I feel that the employers and employees should decide that amongst themselves, because in the end the employer makes his company attractive by offering such opportunities, and employees like such things. The state can do things to make it easier or more attractive to take such steps, but they should keep out of it for the most part, because those are contractual conditions that the employer and employee decide with one another.' (DE-22) This view of state responsibility equates the state with standardisation and providing a framework for negotiations, whereas both families and employers are associated with the option of flexibility and autonomy.

Participants in the UK forum also largely supported the idea of state intervention in providing free childcare for working parents. Childcare was seen as necessary to enable people, especially women, to participate in the labour market and earn an income and to promote equal opportunities between men and women: 'The benefit (of childcare) is that women who can't go back to work full-time because they are looking after children and can't afford childcare, this will help the gender gap. So obviously, men can continue to work, women can also do so as well' (UK-female).

However, participants noted several issues regarding the current childcare system, mirroring much of the German debate. The most important factors were the lack of places, lack of flexibility of opening hours, the need for longer opening hours for parents working different shifts and, most importantly the cost of childcare. Participants placed much more emphasis on costs than those in Germany, reflecting the exceptional level of childcare fees in the UK. This was seen to damage women's employment opportunities and push people out of paid work and onto benefits: '(The cost of childcare) limits women's opportunities because actually to pay for two kids to be in childcare at $\mathfrak{f}_{1,600}$ a month, say, it's actually more beneficial for them to stay at home and look after them and get the benefits than to pay that $\mathfrak{L}_{1}, 600$ because, to get $\mathfrak{E}_{1}, 600$ a month, you'd have to earn $\mathfrak{£}_{25}$,000 a year' (UK-69).

Many participants voiced concerns about providing free childcare for parents who were not employed. Many argued that to be eligible, parents should be required to take part in the labour market, whether voluntary work, training or education. Others argued that the system encourages high fertility rates among the unemployed: ' . . apparently the more children that they seem to have, the more benefits they're going to get so therefore more children are being born and the population is growing again so we're going to have overcrowding' (UK-83). 
Participants believed, as in Germany, that provision at the company level could help provide solutions to these issues - for example, providing in-house crèches. UK participants, unlike those in Germany, were more concerned about the feasibility of these policies, especially for small/medium-sized companies. However, policy solutions are strikingly similar. For example, participants discussed the possibility of forming cooperative crèches between companies. A consensus emerged that governments should provide incentives such as tax breaks, rather than requiring companies to provide these services.

Support for government and employer involvement was generally reinforced by an economic investment perspective: childcare will enable women to work and maintain or improve their skills and will generate higher tax revenues and a more productive economy. 'With more women back in work and earning fair wages then they're going to be paying more tax' (UK-51). 'Yeah. Just to maintain skills. You spend 15 years training somebody up and they're in charge of a team, and it's successful, then you don't want them to leave, do you? Who's going to benefit from it? So, the employer' (UK-44).

The UK participants also valued immediate or extended family support for bonding as in Germany, but believed that much of the care provided informally resulted from the shortcomings and cost of formal childcare. Some recommended payments for informal care but most preferred formal care as offering better socialisation and education: 'It's to benefit the children, not the parents. It's to get children into education sooner' (UK-female).

In sum, the participants' views of the current system, role of the state and other actors in regard to childcare were very similar in the UK and Germany despite their regime differences. The discussion was pitched at a general level and did not differentiate between care for younger and older preschool children. The main contrast lies in the arguments put forward to justify state involvement: in the UK, childcare is seen primarily as an economic investment, to allow mothers to pursue paid work, improve the education of future workers, raise productivity and increase tax revenues; in Germany, childcare, either by state or family, was more frequently justified in terms of broader societal investment contributing to socialisation, self-determination and education.

\section{Discussion and conclusion}

Our study of citizens' responsibility attributions in pensions and childcare reveals similarities as well as marked differences between German and British respondents, both in terms of preferred actor constellations and underlying perceptions of agents in the welfare mix. Table 1 summarises the main findings.

In line with previous research, and following the broad regime differences which underlie our first research question, we find that UK participants are generally more approving of market involvement in social welfare, but German 
TABLE 1. Actor Constellations and Actor Perceptions: Old-Age Pensions and Childcare

\begin{tabular}{|c|c|c|}
\hline & Preferred welfare responsibilities & Dominant actor perceptions \\
\hline $\begin{array}{l}\text { Germany, } \\
\text { old-age } \\
\text { pensions }\end{array}$ & $\begin{array}{l}\text { Three-level pension system: } \\
\text { 1) basic public pension (basis: need); } \\
\text { 2) public pension based on duration of } \\
\text { paid (or non-paid) work (work ethic); } \\
\text { 3) optional top-up private pensions } \\
\text { (financial resources and individual } \\
\text { preferences) }\end{array}$ & $\begin{array}{l}\text { State }=\text { guarantor of basic security } \\
\text { and work-based fairness/equity } \\
\text { Market }=\text { choice, autonomy } \\
\text { Family }=n / a \\
\text { Substantial consensus }\end{array}$ \\
\hline $\begin{array}{l}\text { UK, old-age } \\
\text { pensions }\end{array}$ & $\begin{array}{l}\text { Compulsory private provision } \\
\text { Disagreement about (dis)continuation } \\
\text { of state public pension ('strain on the } \\
\text { economy' versus 'safety net') }\end{array}$ & $\begin{array}{l}\text { State }=\text { partly basic security, } \\
\text { but unsustainable and } \\
\text { non-transparent/ } \\
\text { non-accountable } \\
\text { Market }=\text { adequate standard } \\
\text { of living, transparency } \\
\text { Family }=n / a \\
\text { No consensus over sustainability } \\
\text { of state provision }\end{array}$ \\
\hline $\begin{array}{l}\text { Germany, } \\
\text { childcare }\end{array}$ & $\begin{array}{l}\text { State responsible for legal framework and } \\
\text { financing, but family choice on delivery } \\
\text { (through public, private/non-profit, } \\
\text { home/family) Majority favours } \\
\text { professional childcare, but home } \\
\text { childcare accepted, should be } \\
\text { recognised by the state }\end{array}$ & $\begin{array}{l}\text { State }=\text { backer, regulator and } \\
\text { financier } \\
\text { Market = employers and private } \\
\text { sector providing childcare; } \\
\text { flexibility and autonomy } \\
\text { (via negotiated work/childcare } \\
\text { arrangements between } \\
\text { employers and employees) } \\
\text { Family (home childcare) = personal } \\
\text { commitment, socialisation, } \\
\text { and emotional involvement, } \\
\text { but (for many) also lack of } \\
\text { professionalism and opportunities } \\
\text { Considerable consensus }\end{array}$ \\
\hline $\begin{array}{l}\text { UK, } \\
\text { childcare }\end{array}$ & $\begin{array}{l}\text { State responsible for framework and } \\
\text { subsidising services to enable } \\
\text { employability and labour market } \\
\text { participation Preference for } \\
\text { formal childcare }\end{array}$ & $\begin{array}{l}\text { State }=\text { backer, regulator and } \\
\text { financier } \\
\text { Market = employers and private } \\
\text { sector providing childcare } \\
\text { Family (home childcare) }= \\
\text { emotional bond, but little } \\
\text { support since primary objective } \\
\text { is mobilising mothers as workers } \\
\text { Conflicts between those using } \\
\text { childcare for paid work and } \\
\text { the work-shy user; concern } \\
\text { about costs }\end{array}$ \\
\hline
\end{tabular}

citizens support a larger role for other actors, such as the state, family, employers and charities. This is particularly clear for pensions. Citizens in both countries share the diagnosis that the current public pension system is financially unsustainable but differ markedly in their responses. UK participants favour a further 
shift towards market-based individual retirement provision and accept or even actively support diminution of state responsibility for this core policy. In Germany participants argue for a revival of the public pension system and see private provision as a voluntary top-up primarily for higher-earners.

However, regarding the 'new risk' field of childcare, the differences in actor constellations between countries are less pronounced. Both British and German citizens endorse the state as the foremost actor in the financing and regulation of childcare, yet differ in their underlying reasoning about why the state should promote childcare services. UK participants tend to justify state support in economic terms, as enhancing employability and labour market participation for all citizens (or forced 'voluntary' work for the unemployed) and improving productivity. In Germany the reference-point is societal: support for families' individual choices and preferences, and promotion of gender equality by ensuring that the unpaid labour of women is recognised through pension entitlements. Another difference lies in how people think about the family: German citizens accept state support for parents to provide informal childcare but, in the UK, this option receives little support. A third difference reflects the market ethic of individual responsibility in the UK and emerges in the strong condemnation of work-shy parents who free-ride on state-subsidised childcare and fail to fulfil their side of the bargain in pursuing a job.

In sum, we find a substantial regime difference in policy preferences between the countries, primarily for the old-risk policy of pensions. In Germany, the balance between state and market responsibility for pensions is weighted towards the state, first to ensure that everyone's needs are met and then to reflect status differences through additional provision. In the $\mathrm{UK}$, there is considerable disagreement about possible developments and in particular about the likelihood that the state pension will continue in anything approaching its current form, but a general sense that the market should play a much greater and perhaps dominant role in the future. For childcare, on the other hand, there is a substantial policy consensus across both countries in the desirability of major state involvement in provision, in terms of providing a framework, regulation of standards and subsidies or places. The main differences lie in the way participants justify their solutions as well as the role families play in the provision of childcare. These distinctions reflect our previous understanding of the historical legacies in both countries and their regime differences (see Goerres and Tepe, 2011; Chung and Meuleman, 2017). In other words, although at first sight the childcare policy consensus in both countries cuts across regime theory, regime differences remain in the way people justify their priorities.

We draw the following conclusions. In relation to 'old risk' provision at least, there is an obvious market/state regime difference, less marked for childcare. However, when we examine the underlying pattern of justifications we find 
that regime-related differences are most marked for new risks and reflect people's understanding of the policies and of why they should be pursued.

In relation to our research questions, we find a tendency to greater differences between Germany and the UK in attitudes to pensions than to childcare, reflecting regime membership in the first service area and social risk distinctions in the second. Our analysis of understandings and justifications indicates that the emergence of new risks seems to generate convergence in some respects but that underlying ideas and arguments continue to differ, pointing to the persisting impact of welfare regimes in shaping policy preferences.

The democratic forum method is particularly helpful in allowing researchers to explore the ideas and justifications of a group of participants and in examining how people understand an issue and where their priorities lie, with a minimal shaping of the discussion by the preconceptions of researchers. The insights into people's justifications for policy directions in the two areas examined in this research illustrate the strengths of the approach. Democratic forums by their nature cannot provide the representative data that structured surveys generate, but they have complementary strengths and deserve a place in the arsenal of attitude research methods.

\section{Acknowledgements}

The authors gratefully acknowledge the support of the NORFACE Welfare State Futures programme for this project under grant: 462-14-050.

\section{References}

Arts, W. and Gelissen, J. (2001), 'Welfare states, solidarity and justice principles', Acta Sociologica, 44, 283-299.

Ascoli, U. and Ranci, C. (2002, eds.), Dilemmas of the Welfare Mix, New York: Springer US. Blekesaune, M. (2013), 'Economic strain and public support for redistribution: a comparative analysis of 28 European countries', Journal of Social Policy, 42, 57-72.

Blome, A. (2016), 'Normative beliefs, party competition, and work-family policy reforms in Germany and Italy', Comparative Politics, 48, 479-496.

Bonoli, G. (2005), 'The politics of the new social policies', Policy \& Politics, 33, 431-449.

Burkhardt, C., Martin, R., Mau, S. and Taylor-Gooby, P. (2011), 'Differing notions of social welfare? Britain and Germany compared', in J. Clasen (ed.), Converging Worlds of Welfare? British and German Social Policy in the 21st Century, Oxford: Oxford University Press, 15-32.

Chung, H., Hrast, M.F. and Rakar, T. (2018a), 'The provision of care: whose responsibility and why?', in P. Taylor-Gooby and B. Leruth (eds.), Attitudes, Aspirations and Welfare: Social Policy Directions in Uncertain Times, Basingstoke: Palgrave Macmillan, 183-214.

Chung, H. and Meuleman, B. (2017), 'European parents' attitudes towards public childcare provision', European Societies, 19, 49-68.

Chung, H., Taylor-Gooby, P. and Leruth, B. (2018b), 'Political legitimacy and welfare state futures', Social Policy \& Administration, 52, 835-846.

Daly, M. (2011), 'What adult worker model? A critical look at recent social policy reform in Europe from a gender and family perspective', Social Politics, 18, 1-23. 
Deeming, C. and Smyth, P. (2015), 'Social investment after neoliberalism', Journal of Social Policy, 44, 297-318.

Esping-Andersen, G. (1990), The Three Worlds of Welfare Capitalism, Princeton: Princeton University Press.

Esping-Andersen, G. (1999), Social Foundations of Postindustrial Economies, Oxford: Oxford University Press.

ESS. (2018), 'European Social Survey, online data set', http://www.europeansocialsurvey.org/ data/ [accessed 31.03.2018].

Eurostat. (2018), 'Formal childcare by age and duration', http://data.europa.eu/euodp/en/data/ dataset/JL5rITnPOvJI7d7z92 Gtg [accessed 31.03.2018].

Evers, A. (2011), 'Wohlfahrtsmix und soziale Dienste', in A. Evers, R.G. Heinze and T. Olk (eds.), Handbuch Soziale Dienste, Wiesbaden: VS Verlag für Sozialwissenschaften, 265-283.

Ferragina, E. and Seeleib-Kaiser, M. (2015), 'Determinants of a silent (r)evolution', Social Politics, 22, 1-37.

Fishkin, J.S. and Luskin, R.C. (2005), 'Experimenting with a democratic ideal: deliberative polling and public opinion', Acta Politica, 40, 284-298.

Forschungsgruppe Wahlen. (2015), 'Politbarometer November I 2015', http://www. forschungsgruppe.de/Umfragen/Politbarometer/Archiv/Politbarometer_2015/ November_I_2015/ [accessed 31.03.2018].

Fossati, F. (2018), 'Who wants demanding active labour market policies?', Journal of Social Policy, 47, 77-97.

Goerres, A. and Prinzen, K. (2012), 'Can we improve the measurement of attitudes towards the welfare state?', Social Indicators Research, 109, 515-534.

Goerres, A. and Tepe, M. (2011), 'Doing it for the kids? The determinants of attitudes towards public childcare in unified Germany', Journal of Social Policy, 41, 349-372.

Grönlund, K., Bächtiger, A. and Setälä, M. (2014, eds.), Deliberative Mini-Publics: Involving Citizens in the Democratic Process, Colchester: ECPR Press.

IPSOS-Mori. (2015), 'Social Trends', https://www.ipsos.com/ipsos-mori/en-uk/issues-index2007-onwards [accessed 31.03.2018].

ISSP. (2018), 'International Social Survey Programme: "Role of Government" 1985, 1990, 1996, 2006', https://www.gesis.org/issp/modules/issp-modules-by-topic/role-of-government/ cumulation/ [accessed 31.03.2018].

Jenson, J. (2015), 'Social innovation: redesigning the welfare diamond', in A. Nicholls, J. Simon and M. Gabriel (eds.), New Frontiers in Social Innovation Research, Basingstoke: Palgrave Macmillan 89-106.

Jæger, M.M. (2006), 'Welfare regimes and attitudes towards redistribution', European Sociological Review, 22, 157-170.

Lewis, J. (1992), 'Gender and the development of welfare regimes', Journal of European Social Policy, 2, 159-173.

Lewis, J., Knijn, T., Martin, C. and Ostner I. (2008), 'Patterns of development in work/family reconciliation policies for parents in France, Germany, the Netherlands, and the UK in the 200os', Social Politics, 15, 261-286.

Lindh, A. (2015), 'Public opinion against markets? A comparison of 17 countries', Social Policy \& Administration, 49, 887-910.

Lister, R. (2004), 'The third way's social investment state', in J. Lewis and R. Surender (eds.), Welfare State Change: Towards a Third Way?, Oxford: Oxford University Press 157-181.

Lodigiani, R. and Pesenti, L. (2014), 'Public resources retrenchment and social welfare innovation in Italy: welfare cultures and the subsidiarity principle in times of crisis', Journal of Contemporary European Studies, 22, 157-170.

Mau, S. and Sachweh, P. (2014), 'The middle-class in the German welfare state', Social Policy \& Administration, 48, 537-555.

Morel, N., Palier, B. and Palme, J. (2012, eds.), Towards a Social Investment Welfare State? Bristol: Policy Press. 
Natali, D., Keune, M., Pavolini, E. and Seeleib-Kaiser, M. (2018), 'Sixty years after Titmuss', Social Policy \& Administration, 52, 435-448.

OBR: Office for Budget Responsibility. (2015), Economic and Fiscal Outlook - March 2015', London: Her Majesty's Stationery Office.

OECD. (2016), Society at a Glance 2016, Paris: OECD.

OECD. (2018), 'OECD Statistics, Funded Pensions', https://stats.oecd.org/Index.aspx? DataSetCode=PNNI_NEW\# [accessed 30.03.2018].

Oliver, R.J. and Mätzke, M. (2014), 'Childcare expansion in conservative welfare states', Social Politics, 21, 167-193.

Ostner, I. (2010), 'Farewell to the family as we know it', German Policy Studies, 6, 211-244.

Powell, M. and Barrientos, A. (2004), 'Welfare regimes and the welfare mix', European Journal of Political Research, 43, 83-105.

Ritchie, J., Spencer, L. and O'Conner, W. (2003), 'Carrying out qualitative analysis', in J. Ritchie and J. Lewis (eds.), Qualitative Research Practice, Thousand Oaks: SAGE Publications, 219-262.

Ronchi, S. (2018), 'Which roads (if any) to social investment? The recalibration of EU welfare states at the crisis crossroads (2000-2014)', Journal of Social Policy, 47, 459-478.

Sainsbury, D. (1994, ed.), Gendering Welfare States, London: SAGE Publications.

Schøyen, M.A. and Hvinden, B. (2018), 'Intergenerational solidarity and the sustainability of state welfare', in P. Taylor-Gooby and B. Leruth (eds.), Attitudes, Aspirations and Welfare: Social Policy Directions in Uncertain Times, Basingstoke: Palgrave Macmillan, 137-181.

Svallfors, S. (1997), 'Worlds of welfare and attitudes to redistribution', European Sociological Review, 13, 283-304.

Svallfors, S. (2007), 'Class and attitudes to market inequality', in S. Svallfors (ed.), The Political Sociology of the Welfare State, Stanford: Stanford University Press, 189-222.

Svallfors, S. (2012), Welfare Attitudes in Europe, London: ESS.

Taylor-Gooby, P. (2004), New Risks, New Welfare, Oxford: Oxford University Press.

Taylor-Gooby, P. (2017), 'Re-doubling the crises of the welfare state', Journal of Social Policy, $46,815-835$.

Taylor-Gooby, P., Chung, H. and Leruth, B. (2018), 'The contribution of deliberative forums to studying welfare state attitudes', Social Policy \& Administration, 52, 914-927.

Taylor-Gooby, P. and Leruth, B. (2018, eds.), Attitudes, Aspirations and Welfare: Social Policy Direction in Uncertain Times, Basingstoke: Palgrave Macmillan.

Taylor-Gooby, P., Leruth, B. and Chung, H. (2017, eds.), After Austerity: Welfare State Transformation in Europe After the Great Recession, Oxford: Oxford University Press.

Vandenbroucke, F., Hemerijck, A. and Palier, B. (2011), 'The EU needs a social investment pact', OSE Opinion paper 5. Brussels: Observatoire Social Europeene.

Wakeford, T. and Singh, J. (2008), 'Towards empowered participation', Participatory Learning and Action, 58, 6-9. 